\title{
Performance, Growth Curves and Carcass Yield of Four Strains of Broiler Chicken
}

http://dx.doi.org/10.1590/1806-9061-2018-0866

\section{-Author(s)}

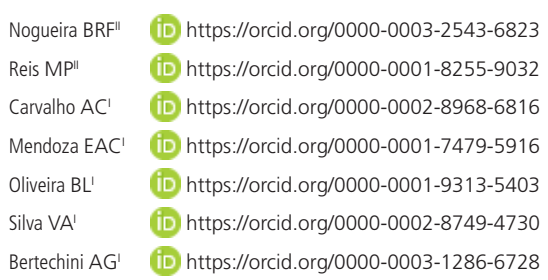

Department of Animal Science, Federal University of Lavras, Lavras, CEP: 37200-000, Minas Gerais, Brazil.

" Department of Animal Science, São Paulo State University, Jaboticabal, 14884-900, São Paulo, Brazil.

\section{ABSTRACT}

The objective of this study was to evaluate the performance, carcass yield and growth curves of different commercial strains of broiler chicken. 2400 day-old chicks, males and females of the Cobb500, RossAp95, Hubbard Flex and a new Francesa line were used. The birds were distributed in a completely randomized design in a factorial arrangement $4 \times 2$ (line $x$ sex), forming eight treatments with 10 replicates each. The birds were fed with the same diet. Feed intake, weight gain and feed conversion were determined. At 42 days, it was determined at the request of carcass and cuts of each lineage. The Gompertz model was applied to a growth curve for each line. The RossAP95 line shows the best performance results. Growth curves showed lower sexual dimorphism in the Hubbard Flex line. The Hubbard Flex strain presented higher thigh yield and a Cobb500 genetics the higher breast yield. Based on the results found it was observed that the RossAP95 performed better. Hubbard Flex line exhibits the least sexual dimorphism. The Cobb500 have better yield for breast and as Hubbard Flex birds greater thigh yield.

\section{INTRODUCTION}

The genetic engineering of broiler chicken breeding programs has achieved levels never reached by any other animal species, making the chicken meat sector efficient in producing protein of high biological value. Selecting characteristics for better performance, resulted in improvement in feed efficiency and weight gain, modifying the growth curve and the nutritional requirement of the broiler strains. The mastery and advancement of the genetic improvement of broiler strains generated a competitive and qualified chicken meat genetics market, in which each breeding company has its selection criteria providing strains that, although similar, have particularities of their own.

Genetic companies sell their brands evidencing their strain and highlighting characteristics such as differentiated cuts, resistance to diseases, higher weight gain and better feed conversion. Researches show that there is a difference in the carcass yield of strains, while some have a higher breast yield, others have a higher yield of drumstick and thigh. (Cheema et al., 2003; Garcia Neto \& Campos, 2004; Havenstein et al., 1994a, 1994b; Lopez et al., 2011).

To understand the observed differences during growth of broilers among strain and sex, mathematical models is an excellent tool. Gompertz function have been proved to have a good fit for data of chicken's body weight (Emmans, 1997). In addition, the parameters of this function have biological meaning, which means that an interpretation might be applied directly to the observed data (Gous, 2014). Furthermore, the first derivative of Gompertz function will bring interesting information about the observed data, as discussed herein. 
In this context, growth curves could be used for two main purposes, to describe the genetic potential that will be used as input for mechanistic models, as described by Sakomura et al. (2015); and on the other hand, to produce a valuable information that allows a comparation between strains and sex, which was the approach adopted in this manuscript.

Tests with commercial strains of broiler chicken become fundamental since characteristics of economic importance and of market preferences may be different between genetic ones, being this evaluation highly relevant for the chicken meat industry in the choice of the best strain, which hence results in better production indices.

Based on the above, we hypothesized that there are differences among strains of broiler chickens available in the market, hence, the aim of the present study was to evaluate the differences in performance and carcass yield of four strains of broiler chicken, besides estimating their growth parameters.

\section{MATERIAL AND METHODS}

All experimental procedures were evaluated and approved (protocol $n^{\circ}$ 007/17) by the Ethics Committee on Animal use of the Federal University of Lavras.

A performance experiment was ran at the Centro de Pesquisa e Tecnologia Avicola(CPTA) located at BR 265, $\mathrm{Km} \mathrm{344,} \mathrm{in} \mathrm{agreement} \mathrm{with} \mathrm{the} \mathrm{Federal} \mathrm{University} \mathrm{of}$ Lavras (UFLA), using 300 male and 300 female chickens from the Cobb-500 $(39 g \pm 3)$, Ross AP $95(43 g \pm 5)$, Hubbard Flex $(39 g \pm 2)$ and a new French $(37 g \pm 2)$ strain, totaling 2400 animals ranging from 1 day of age up to 42 days. The birds were reared in 80 pens $(2.0$ $x 1.1 \mathrm{~m}$ ) in a litter system (new wood shaving), where they were randomly distributed in eight treatments in a $4 \times 2$ factorial design (strain $x$ sex) with 10 replications per treatment. Each experimental pen contained one tubular feeder $(25 \mathrm{~kg})$ and five in-line nipple drinkers. The experimental pen was represented by 30 initial birds (13.6 birds $\left./ \mathrm{m}^{2}\right)$. The light program was 24L:OD from one to 14 days and from there on 18L:6D until slaughter.

The birds received the same feed that were formulated according to the nutritional requirements established by Rostagno et al. (2011). The diets were pelletized, grounded and supplied ad libitum throughout the experiment. The feeding program consisted of four diets distributed in: Pre-started ( 1 to 7 days), Started (8 to 21 days), Growth (22 to 35 days) and Final (36 to 42 days) and are presented in Table 1.
Table 1 - Percentage composition of feed ingredients and nutritional levels of feeds.

\begin{tabular}{|c|c|c|c|c|}
\hline Ingredient & Pre-started & Started & Growth & Final \\
\hline Corn & 48.600 & 52.800 & 56.440 & 61.210 \\
\hline Soybean meal & 42.600 & 37.000 & 33.300 & 29.300 \\
\hline Soybean oil & 4.200 & 6.000 & 6.400 & 5.900 \\
\hline Dicalcium phosphate & 2.000 & 1.800 & 1.600 & 1.600 \\
\hline Limestone & 0.800 & 0.800 & 0.800 & 0.800 \\
\hline Salt & 0.370 & 0.380 & 0.370 & 0.3600 \\
\hline Sodium bicarbonate & 0.198 & 0.100 & 0.100 & 0.100 \\
\hline DL-Methionine 99 & 0.419 & 0.368 & 0.324 & 0.289 \\
\hline L-lysine HCL 78 & 0.214 & 0.196 & 0.184 & 0.175 \\
\hline L-Threonine 98 & 0.101 & 0.082 & 0.079 & 0.065 \\
\hline Premix initial'12 & 0.400 & 0.400 & 0.00 & 0.000 \\
\hline Premix growth ${ }^{12}$ & 0.000 & 0.000 & 0.400 & 0.000 \\
\hline Premix final|12 & 0.000 & 0.000 & 0.00 & 0.200 \\
\hline \multicolumn{5}{|l|}{ Nutritional composition } \\
\hline Metabolizable energy (Kcal/kg) & 2960 & 3130 & 3250 & 3280 \\
\hline Crude protein (\%) & 23.300 & 21.000 & 19.507 & 18.00 \\
\hline Calcium (\%) & 0.960 & 0.900 & 0.850 & 0.800 \\
\hline Available phosphorus (\%) & 0.480 & 0.450 & 0.410 & 0.400 \\
\hline Sodium (\%) & 0.220 & 0.195 & 0.190 & 0.190 \\
\hline Dig. L-lysine (\%) & 1.350 & 1.200 & 1.100 & 1.000 \\
\hline Dig. DI-methionine (\%) & 0.712 & 0.637 & 0.577 & 0.527 \\
\hline Met.+Cis. Dig (\%) & 1.026 & 0.924 & 0.847 & 0.780 \\
\hline Dig. threonine (\%) & 0.850 & 0.756 & 0.704 & 0.640 \\
\hline Dig. tryptophan (\%) & 0.244 & 0.217 & 0.199 & 0.180 \\
\hline Dig. arginine (\%) & 1.479 & 1.309 & 1.203 & 1.094 \\
\hline
\end{tabular}

1Supplemented per kg of product: vitamin A - 12,000 IU; vitamin D3 - 2,500 IU; vitamin E - 30 IU; vitamin B1 - 2 mg; vitamin B6 - 3 mg; calcium pantothenate $10 \mathrm{mg}$; biotin 0.07 mg; vitamin $\mathrm{k3}$ - 3 mg; folic acid - 1 mg; nicotinic acid - 35 mg; vit. B12 - $15 \mu g$; selenium - $0.12 \mathrm{mg}$; BHT - $5 \mathrm{mg}$.

2 Supplemented per kg of product: manganese - 80 mg; iron - 50 mg; zinc - 50 mg; copper - $10 \mathrm{mg}$; cobalt - $1 \mathrm{mg}$; iodine - $1 \mathrm{mg}$.

For the performance analysis, the bird's weights and feed leftovers were collected weekly to calculate feed intake (FI), weight gain (WG) and feed conversion (FC).

The weekly weight gain data were used to fit a growth curve for each strain and for each sex, following the model of Gompertz (1825). The fitted model can predict the daily average weight and the derived equation can predict the daily weight gain of the birds. The model used was:

$\mathrm{Pt}=\mathrm{Pm} \cdot \exp \cdot\left(-\exp \cdot\left(-\mathrm{b} \cdot\left(\mathrm{t}-\mathrm{t}^{*}\right)\right)\right)$

Where: $P t=$ weight $(g)$ of the bird at time $t$, expressed as a function of $\mathrm{Pm} ; \mathrm{Pm}=$ weight $(\mathrm{g})$ at maturity of bird; $b=$ maturity rate (per day); $t^{*}=$ time (days) where the growth rate is maximal.

At 42 days, two birds per experimental pen were slaughtered and plucked to determine carcass yield, cuts (breast, sassami, drumstick, thigh, breast fillet) and edible viscera (heart, gizzard and liver) according to the following formulas:

- Plucked carcass yield (CY) without viscera, foot and head, in relation to the live weight of broiler. 
CY $(\%)=($ carcass weight / live weight $) * 100$

Cut Yield $(\%)=$ (cut weight / carcass weight) * 100

The experimental data were analyzed using the SAS software (2002) and a two-way ANOVA was performed to determine the main effects (strain $x$ sex) and their interactions. When there were interactions, the factors were unfolded, and when there was no interaction, the factors were analyzed separately. Averages were compared applying the Tukey test for the strains and the $\mathrm{F}$ test for the sex. The differences were considered as significant at $5 \%$ probability.

\section{RESULTS AND DISCUSSION}

The performance results are presented in Tables 2 and 3. There was a significant interaction $(p<.005)$ between the sex and strain factors in all the observed phases, demonstrating that males and females of a certain strain showed different variations, i.e., males and females within certain genetics may be more homogeneous in relation to others. On the other hand, Stringhini et al. (2003) did not observe the interaction between strain and sex when evaluating performance of Ross, Cobb, Avian Farms, and Arbor Acres strains.

There was a significant interaction $(p<.005)$ among the factors for the variables WG and $\mathrm{Fl}$, in which the French, Hubbard and Cobb showed greater homogeneity between males and females, differently from Ross in which the males presented greater weight gain in the first week when compared to the females. Similar result to Da Costa et al. (2017) was found when evaluating the performance of the Ross strain in mixed or single sex, the males had higher WG than females. The results observed in the WG are justified by the increase in the $\mathrm{Fl}$ of the birds, i.e., birds with higher $\mathrm{FI}$ showed higher WG, justifying the absence of significant results ( $p>$.005) for the FC variable. Eggs from the strains Cobb and Ross differ in nutrient availability, embryonic development and nutrient metabolism during incubation, and the amount of gross energy used by Ross 308 embryos was higher than the Cobb 500 embryos (Nangsuay et al., 2015). This fact can reflect in the first week of raising, justifying the superiority of the Ross strain in this phase in relation to the other strains.

In the second and third weeks of the experiment, a different behavior was observed for the WG in all strains, being that males had highest WG $(p<.005)$ than females, demonstrating that regardless of the studied strain, there was superiority of males in relation to females for WG.

At 35 days of age, a significant interaction between sex and strain was observed for WG and FI variables $(p<.005)$, being possible to observe differences

Table 2 - Weight gain (WG) in kilograms, feed intake (FI) in kilograms and feed conversion (FC) of the first three weeks of broiler breeding from different strains, males and females.

\begin{tabular}{|c|c|c|c|c|c|c|c|c|c|c|}
\hline \multirow[b]{2}{*}{ Strain } & \multirow[b]{2}{*}{ Sex } & \multicolumn{9}{|c|}{ Performance } \\
\hline & & WG7 & $\mathrm{FI7}$ & FC7 & WG14 & $\mathrm{Fl14}$ & FC14 & WG21 & $\mathrm{Fl} 21 \mathrm{~g}$ & FC21 \\
\hline \multirow{2}{*}{ French } & $M$ & $0.166 \mathrm{~cd}$ & $0.173 c$ & 1.039 & $0.476 a$ & $0.620 c$ & 1.305 & $0.924 \mathrm{~b}$ & $1.248 c$ & 1.351 \\
\hline & $\mathrm{F}$ & $0.161 \mathrm{~d}$ & $0.168 c$ & 1.044 & $0.447 d$ & $0.616 c$ & 1.378 & $0.858 c$ & $1.243 c$ & 1.449 \\
\hline \multirow{2}{*}{ Hubbard Flex } & M & $0.164 \mathrm{~cd}$ & $0.172 c$ & 1.047 & $0.479 c$ & $0.620 c$ & 1.295 & $0.929 b$ & $1.247 c$ & 1.342 \\
\hline & $\mathrm{F}$ & $0.162 d$ & $0.172 c$ & 1.060 & $0.450 d$ & $0.619 c$ & 1.379 & $0.876 c$ & $1.246 c$ & 1.423 \\
\hline \multirow{2}{*}{ Cobb 500} & M & $0.180 \mathrm{~b}$ & $0.188 b$ & 1.047 & $0.503 b$ & $0.635 b$ & 1.264 & $0.920 b$ & $1.263 \mathrm{~b}$ & 1.374 \\
\hline & $\mathrm{F}$ & $0.174 \mathrm{cb}$ & $0.184 b$ & 1.062 & $0.466 \mathrm{~cd}$ & $0.632 b$ & 1.358 & $0.875 c$ & $1.259 \mathrm{~b}$ & 1.440 \\
\hline \multirow{2}{*}{ Ross AP95 } & M & $0.195 a$ & $0.205 a$ & 1.054 & $0.540 \mathrm{a}$ & $0.653 a$ & 1.211 & $0.998 a$ & $1.279 \mathrm{a}$ & 1.283 \\
\hline & $\mathrm{F}$ & $0.177 b$ & $0.188 \mathrm{~b}$ & 1.064 & $0.487 b c$ & $0.636 b$ & 1.307 & $0.918 b$ & $1.263 \mathrm{~b}$ & 1.376 \\
\hline \multicolumn{11}{|l|}{ Main Effect } \\
\hline \multirow{4}{*}{ Strain } & French & 0.164 & 0.171 & 1.042 & 0.460 & 0.618 & $1.346 \mathrm{~b}$ & 0.891 & 1.245 & $1.400 \mathrm{~b}$ \\
\hline & Hubbard Flex & 0.163 & 0.172 & 1.054 & 0.464 & 0.620 & $1.337 b$ & 0.904 & 1.246 & $1.380 \mathrm{~b}$ \\
\hline & Cobb 500 & 0.177 & 0.186 & 1.054 & 0.484 & 0.634 & $1.311 \mathrm{~b}$ & 0.899 & 1.261 & $1.405 b$ \\
\hline & Ross AP95 & 0.186 & 0.197 & 1.059 & 0.514 & 0.645 & $1.259 \mathrm{a}$ & 0.956 & 1.271 & $1.332 \mathrm{a}$ \\
\hline \multirow{2}{*}{ Sex } & $M$ & 0.177 & 0.185 & 1.047 & 0.501 & 0.633 & $1.267 \mathrm{a}$ & 0.941 & 1.259 & $1.339 a$ \\
\hline & $\mathrm{F}$ & 0.168 & 0.178 & 1.057 & 0.462 & 0.626 & $1.355 \mathrm{~b}$ & 0.882 & 1.253 & $1.421 \mathrm{~b}$ \\
\hline \multirow{4}{*}{$p$-Value } & $C V$ & 3.802 & 3.796 & 2.865 & 3.155 & 1.107 & 2.713 & 2.140 & 0.548 & 2.092 \\
\hline & Strain & 0.320 & $<.0001$ & 0.321 & $<.0001$ & $<.0001$ & $<.0001$ & $<.0001$ & $<.0001$ & $<.0001$ \\
\hline & Sex & $<.0001$ & $<.0001$ & 0.127 & $<.0001$ & 0.000 & $<.0001$ & $<.0001$ & $<.0001$ & $<.0001$ \\
\hline & Interaction & 0.002 & 0.002 & 0.957 & 0.020 & 0.002 & 0.582 & 0.035 & 0.006 & 0.306 \\
\hline
\end{tabular}

'Averages with different letters on the same column differ statistically by Tukey test at $5 \%$ probability. 
Table 3 - Weight gain (WG) in kilograms, feed intake (FI) in kilograms and feed conversion (FC) of the fifth and sixth weeks of broiler breeding from different strains, males and females.

\begin{tabular}{|c|c|c|c|c|c|c|c|c|c|c|}
\hline \multicolumn{2}{|l|}{ Treatment } & \multicolumn{9}{|c|}{ Performance } \\
\hline Strain & Sex & WG28 & $\mathrm{FI} 28$ & FC28 & WG35g & $\mathrm{Fl} 35 \mathrm{~g}$ & FC35 & WG42 & $\mathrm{Fl} 42$ & FC42 \\
\hline \multirow{2}{*}{ French } & $\mathrm{M}$ & 1.770 & $2.323 c$ & 1.311 & $2.571 \mathrm{~b}$ & $3.636 \mathrm{c}$ & 1.415 & $3.293 \mathrm{~b}$ & $4.983 \mathrm{C}$ & $1.515 b$ \\
\hline & $\mathrm{F}$ & 1.565 & $2.319 c$ & 1.482 & $2.216 \mathrm{~d}$ & $3.631 \mathrm{c}$ & 1.639 & $2.797 \mathrm{~d}$ & 4.977 c & $1.780 \mathrm{de}$ \\
\hline \multirow{2}{*}{ Hubbard Flex } & $M$ & 1.753 & $2.323 c$ & 1.326 & $2.526 b$ & $3.635 c$ & 1.440 & 3.196 b & $4.981 c$ & $1.559 \mathrm{~b}$ \\
\hline & $\mathrm{F}$ & 1.577 & $2.322 \mathrm{c}$ & 1.473 & $2.240 \mathrm{~d}$ & $3.634 c$ & 1.623 & $2.843 \mathrm{~cd}$ & $4.980 \mathrm{C}$ & $1.752 \mathrm{~cd}$ \\
\hline \multirow{2}{*}{ Cobb 500} & M & 1.745 & $2.339 \mathrm{~b}$ & 1.341 & $2.544 b$ & $3.651 \mathrm{~b}$ & 1.436 & 3.204 b & 4.998 C & $1.560 \mathrm{~b}$ \\
\hline & $\mathrm{F}$ & 1.563 & $2.335 \mathrm{~b}$ & 1.494 & $2.198 d$ & $3.647 b$ & 1.660 & $2.752 \mathrm{~d}$ & $4.993 \mathrm{~b}$ & $1.815 \mathrm{e}$ \\
\hline \multirow{2}{*}{ Ross AP95 } & M & 1.876 & $2.356 \mathrm{a}$ & 1.256 & $2.736 a$ & $3.668 \mathrm{a}$ & 1.340 & $3.445 a$ & $5.014 a$ & $1.456 \mathrm{a}$ \\
\hline & $\mathrm{F}$ & 1.666 & $2.339 \mathrm{~b}$ & 1.405 & $2.351 \mathrm{c}$ & $3.650 \mathrm{~b}$ & 1.550 & $2.915 c$ & $4.997 \mathrm{~b}$ & $1.715 c$ \\
\hline \multicolumn{11}{|l|}{ Main effect } \\
\hline \multirow{4}{*}{ Strain } & French & $1.657 b$ & 2.321 & $1.406 \mathrm{~b}$ & 2.413 & 3.634 & $1.514 b$ & 3.032 & 4.980 & 1.654 \\
\hline & Hubbard Flex & $1.665 \mathrm{~b}$ & 2.323 & $1.400 \mathrm{~b}$ & 2.383 & 3.635 & $1.532 \mathrm{~b}$ & 3.029 & 4.981 & 1.651 \\
\hline & Cobb 500 & $1.659 b$ & 2.337 & $1.414 b$ & 2.380 & 3.649 & $1.542 b$ & 2.978 & 4.996 & 1.687 \\
\hline & Ross AP95 & $1.77 \mathrm{a}$ & 2.348 & $1.331 \mathrm{a}$ & 2.554 & 3.660 & $1.442 \mathrm{a}$ & 3.180 & 5.006 & 1.586 \\
\hline \multirow{2}{*}{ Sex } & $\mathrm{M}$ & $1.788 \mathrm{a}$ & 2.336 & $1.308 \mathrm{a}$ & 2.594 & 3.647 & $1.408 \mathrm{a}$ & 3.287 & 4.994 & 1.522 \\
\hline & $\mathrm{F}$ & $1.594 b$ & 2.329 & $1.463 \mathrm{~b}$ & 2.252 & 3.641 & $1.618 b$ & 2.828 & 4.987 & 1.765 \\
\hline \multirow{4}{*}{$p$-value } & CV & 2.170 & 0.298 & 2.072 & 2.303 & 0.191 & 2.196 & 2.432 & 0.138 & 2.256 \\
\hline & Strain & $<.0001$ & $<.0001$ & $<.0001$ & $<.0001$ & $<.0001$ & $<.0001$ & $<.0001$ & $<.0001$ & $<.0001$ \\
\hline & Sex & $<.0001$ & 0.000 & $<.0001$ & $<.0001$ & 0.000 & $<.0001$ & $<.0001$ & $<.0001$ & $<.0001$ \\
\hline & Interaction & 0.323 & 0.002 & 0.615 & 0.043 & 0.002 & 0.174 & 0.003 & 0.005 & 0.012 \\
\hline
\end{tabular}

${ }^{1}$ Averages with different letters on the same column differ statistically by Tukey test at $5 \%$ probability.

between males and females among all strains, in which chicken from Ross strain were superior to the others, regardless of the sex. The other strains had similar performance. The females of the Cobb 500 strain had FI similar to the females of the Ross Ap 95 strain, although with significant differences $(p<.005)$ for WG, demonstrating greater efficiency in grasping the nutrients of the Ross genetics. Such results were contrary to those found by Vieira et al., 2007, which observed higher precocity of Cobb females in the first raising phase. The strains Hubbard, French and Cobb had similar results between males and females for the FI variable, but with significant differences for WG. This fact demonstrates that the strains French, Hubbard and Cobb show different behavior in relation to the Ross strain, i.e., Ross males have a higher FI when compared to females from the same strain $(p<.005)$, which was not observed in other strains.

When analyzing the total raising period, there was significant interaction $(p<.005)$ in all the analyzed variables. The females of the Hubbard strain showed improvement in WG at the end of raising, so the differences between males and females were smaller for this strain in relation to the other strains, showing better uniformity between males and females for the Hubbard strain.

Males of the Ross strain had Fl, WG and FC higher than chicken from the other strains $(p<.005)$, differently from other studies that did not show differences among the strains for FC at the end of raising (Api et al., 2017; Peak et al., 2000; Stringhini et al., 2003). Dalólio et al. (2016) evaluated levels of digestible lysine in the final phase of the raising of three broiler chicken strains and observed that the chickens of the Cobb 500 strain had higher $\mathrm{FI}$ than the strains Hubbard Flex and Ross 308 but did not differ in WG and FC.

The WG of current commercial strains increased about $400 \%$ with a simultaneous reduction of $50 \%$ FC index in 50 years (Zuidhof et al., 2014), modifying the growth behavior of these chickens. The growth curves obtained in the present study can be used as tools to evaluate the growth pattern of the studied strains. The results are presented in Table 1 and Figures 1 and 2 .

When analyzing Figures 1 and 2 and Table 4 it can be observed that, among males, the French strain reached the maximum weight gain at 32 days of age $(116 \mathrm{~g})$, with later growth in relation to other strains. Hubbard males reached the maximum rate of $110 \mathrm{~g} \mathrm{WG}$ daily at 29 days, whereas Ross males were the most precocious reaching $119 \mathrm{~g} \mathrm{WG}$ per day at 31 days.

When evaluating the growth curves of broiler chicken strains, Fernandes et al., (2013) had similar results to those in which the strains Cobb Fast, Ross 308, Ross 508, Hybro Plus and Avian 48, regardless of sex, reached their maximum weight gain between 32 and 35 days. However, the Cobb 500 Slow strain showed potential for maximum weight gain up to 47 days of age. 
Nogueira BRF, Reis MP, Carvalho AC, Mendoza EAC, Oliveira BL, Silva VA, Bertechini AG

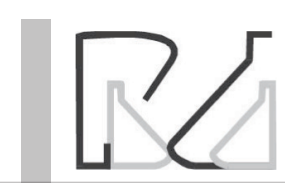

Performance, Growth Curves and Carcass Yield of Four Strains of Broiler Chicken

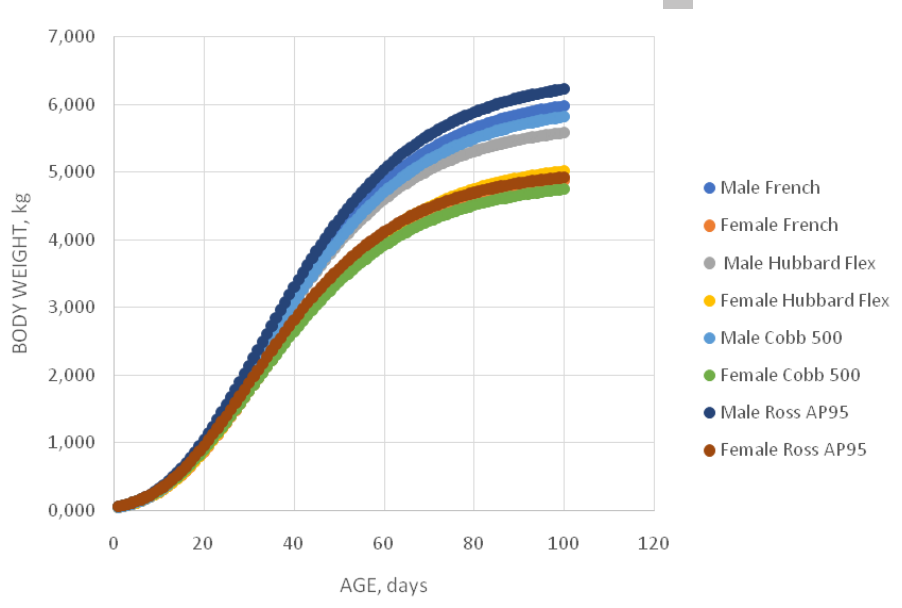

Figure 1 - Estimated weight according to days, according to strain and sex.

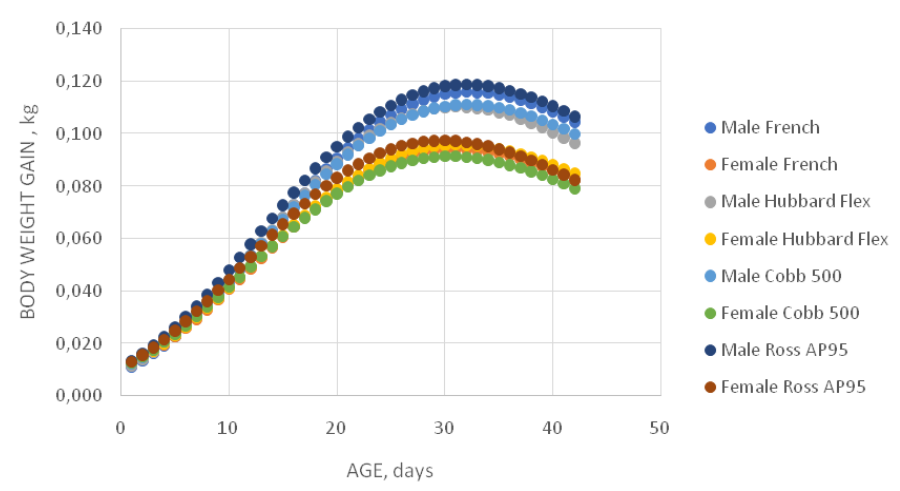

Figure $\mathbf{2}$ - Estimated weight gain in relation to raising days.

Hubbard males upon reaching the Dmax were the most persistent among males and maintained their curve longer in the plateau (four days). Among females, the Cobb strain was the most persistent, maintaining its maximum weight gain for five days. According to Kesller (2000), the longer the chicken takes to reach the inflection point of the protein deposition curve, the more efficient the individual will be to produce meat and the better the carcass composition.

Table 4 - Estimated day for maximum weight gain (DMax), estimated day of first fall in rate of weight gain (1 fall) and estimated WG determined on the day of DMax (WGDay).

\begin{tabular}{|c|c|c|c|c|}
\hline Strain & & DMax & 1 fall & WGDay(g) \\
\hline French & \multirow{4}{*}{ Males } & 32 & 34 & 116 \\
\hline Hubbard Flex & & 29 & 34 & 110 \\
\hline Cobb 500 & & 31 & 35 & 111 \\
\hline Ross AP95 & & 31 & 34 & 119 \\
\hline French & \multirow{4}{*}{ Females } & 29 & 34 & 94 \\
\hline Hubbard Flex & & 30 & 34 & 96 \\
\hline Cobb 500 & & 28 & 34 & 91 \\
\hline Ross AP95 & & 28 & 33 & 97 \\
\hline
\end{tabular}

In the growth behavior of females among the different strains, it is noted that the Ross strain was also the most precocious, however, it is worth mentioning that the differences among the strains for males were much greater than for females. An important fact is that the Hubbard females had a curve close to males of the same strain, highlighting the observed performance data.

Some studies comparing the growth of broiler chicken strains observed a higher precocity of the Cobb strain in relation to the other ones (Danisman et al., 2011; Faridi et al., 2012; Marcato et al., 2010; Sakomura et al., 2011; Vieira et al., 2007), different from the present study, in which higher precocity for the Ross strain was observed.

Analyzing the growth curve of the Hubbard strain, it was observed that the chicken of this strain was the most persistent when it reached the maximum daily gain, remaining six days at maximum gain.

The results of carcass yield and cuts are presented in Table 5.

Among the analyzed variables, only wing yield showed a significant interaction $(p<.005)$, with the Cobb females yielding lower than the males. Contrary situation occurred with the French chicken, since the females had higher yield of that cut than the males.

For the carcass yield, there was no difference among the strains $(p>.005)$. The same occurred when the average between males and females was compared, in which other studies did not observe significant differences between the strains and sex (Api et al., 2017; Stringhini et al., 2003).

For the breast cut, the Hubbard strain showed the lowest yield among the strains $(p<.005)$. The same can be observed for the breast fillet; however, no difference was observed among the strains ( $p>0.005)$ for the sassami, being that the Hubbard chicken had the highest result for this variable, demonstrating that the fillet yield was responsible for the fall in the breast yield.

For drumstick yield, differences among strains and between males and females $(p<.005)$ were observed, the males showed the highest result for this variable. Unlike the observed for breast yield, Hubbard chicken had the highest value for drumstick yield. Regardless of the evaluated strain, the males showed the highest result for this variable.

Cobb presented the worst result among the evaluated strains $(p<.005)$ for the thigh yield.

When evaluating the cut yields of broiler chicken strains, some studies (Api et al., 2017; Dalólio et al., 2016) observed greater breast yield for Cobb strain and greater drumstick yield for Hubbard, results similar to the present study. 
Table 5 - Yield of carcass and cuts (\%) of four strains of male and female broiler chicken.

\begin{tabular}{|c|c|c|c|c|c|c|c|c|}
\hline Strain & Sex & Carcass & Breast weight & Fillet breast & Sassami & Drumstick & Thigh & Wing \\
\hline & $M$ & 78.90 & 35.53 & 22.46 & 5.13 & 12.44 & 17.87 & $12.09 \mathrm{ab}$ \\
\hline French & $\mathrm{F}$ & 78.89 & 35.04 & 21.66 & 5.66 & 11.91 & 16.78 & $12.51 \mathrm{a}$ \\
\hline \multirow{2}{*}{ Hubbard Flex } & M & 78.23 & 33.31 & 20.18 & 5.12 & 13.26 & 18.00 & $11.91 \mathrm{ab}$ \\
\hline & $\mathrm{F}$ & 78.72 & 34.83 & 20.93 & 5.83 & 12.28 & 17.58 & $11.93 \mathrm{ab}$ \\
\hline \multirow{2}{*}{ Cobb 500} & M & 80.52 & 36.58 & 23.28 & 5.06 & 12.16 & 16.87 & $12.21 \mathrm{ab}$ \\
\hline & $\mathrm{F}$ & 79.09 & 37.71 & 23.49 & 5.34 & 11.14 & 15.84 & $11.14 b$ \\
\hline \multirow{2}{*}{ Ross AP95 } & M & 79.26 & 36.33 & 23.49 & 4.90 & 12.08 & 17.46 & $11.37 \mathrm{ab}$ \\
\hline & $\mathrm{F}$ & 79.55 & 35.72 & 22.36 & 5.39 & 11.87 & 17.29 & $11.89 \mathrm{ab}$ \\
\hline \multicolumn{9}{|l|}{ Main effect } \\
\hline \multirow{4}{*}{ Strain } & French & 78.89 & $35.29 b c$ & $22.06 a$ & 5.40 & $12.17 \mathrm{ab}$ & $17.32 \mathrm{a}$ & 12.30 \\
\hline & Hubbard Flex & 78.48 & $34.07 c$ & $20.56 b$ & 5.48 & 12.77 a & $17.79 a$ & 11.92 \\
\hline & Cobb 500 & 79.81 & $37.14 \mathrm{a}$ & $23.38 a$ & 5.20 & $11.65 b$ & $16.35 b$ & 11.68 \\
\hline & Ross AP95 & 79.40 & $36.06 a b$ & $22.92 \mathrm{a}$ & 5.15 & $11.97 b$ & $17.38 \mathrm{a}$ & 11.63 \\
\hline \multirow{2}{*}{ Sex } & $M$ & 79.23 & 35.44 & 22.35 & $5.05 b$ & $12.48 \mathrm{a}$ & $17.55 \mathrm{a}$ & 11.90 \\
\hline & $\mathrm{F}$ & 79.06 & 35.82 & 22.11 & $5.56 \mathrm{a}$ & $11.80 \mathrm{~b}$ & $16.87 \mathrm{~b}$ & 11.87 \\
\hline \multirow{4}{*}{$p$-Value } & $C V$ & 2.608 & 5.229 & 7.775 & 8.745 & 6.115 & 5.976 & 7.464 \\
\hline & Strain & 0.199 & $<.0001$ & $<.0001$ & 0.085 & $<.0001$ & $<.0001$ & 0.074 \\
\hline & Sex & 0.718 & 0.357 & 0.528 & $<.0001$ & $<.0001$ & 0.005 & 0.876 \\
\hline & Interaction & 0.454 & 0.167 & 0.289 & 0.554 & 0.258 & 0.409 & 0.023 \\
\hline
\end{tabular}

${ }^{1}$ Averages with different letters on the same column differ statistically by Tukey test at $5 \%$ probability.

The yield results of edible viscera and feet are presented in Table 6 . There was no interaction between the factors ( $p>0.05)$ strain and sex for yields of edible viscera and feet. Research indicate that there is a superiority of females in relation to males regardless of age (Api et al., 2017; Stringhini et al., 2003) for these variables, corroborating with the results verified in the present study.

Table 6 - Yield of edible viscera and feet (\%) of four strains of broiler chicken.

\begin{tabular}{lccccc}
\hline Strain & Sex & Liver & Heart & Gizzard & Feet \\
\hline \multirow{2}{*}{ French } & $\mathrm{M}$ & 1.81 & 0.603 & 2.10 & 4.35 \\
& $\mathrm{~F}$ & 2.06 & 0.693 & 2.80 & 5.02 \\
Hubbard Flex & $\mathrm{M}$ & 1.77 & 0.573 & 2.14 & 4.01 \\
& $\mathrm{~F}$ & 2.06 & 0.716 & 2.32 & 4.55 \\
Cobb 500 & $\mathrm{M}$ & 1.83 & 0.576 & 2.12 & 3.73 \\
& $\mathrm{~F}$ & 2.09 & 0.703 & 2.56 & 4.96 \\
Ross AP95 & $\mathrm{M}$ & 1.75 & 0.556 & 2.00 & 3.82 \\
& $\mathrm{~F}$ & 1.88 & 0.681 & 2.33 & 4.46 \\
\hline Main effect & & & & & \\
\hline \multirow{5}{*}{ Strain } & French & 1.93 & 0.648 & 2.45 & 4.68 \\
& Hubbard & 1.91 & 0.644 & 2.23 & 4.28 \\
& $\mathrm{Flex}$ & & & \\
& Cobb 500 & 1.96 & 0.639 & 2.34 & 4.34 \\
Sex & Ross Ap95 & 1.81 & 0.618 & 2.16 & 4.14 \\
& $\mathrm{M}$ & $1.79 \mathrm{~b}$ & $0.577 \mathrm{~b}$ & $2.09 \mathrm{~b}$ & $3.98 \mathrm{~b}$ \\
& $\mathrm{~F}$ & $2.02 \mathrm{a}$ & $0.698 \mathrm{a}$ & $2.50 \mathrm{a}$ & $4.75 \mathrm{a}$ \\
\multirow{4}{*}{ p-Value } & $\mathrm{CV}$ & 15.039 & 21.637 & 18.676 & 18.054 \\
& Strain & 0.383 & 0.902 & 0.173 & 0.169 \\
& Sex & 0.001 & $<.0001$ & $<.0001$ & 0.001 \\
& Interaction & 0.824 & 0.940 & 0.279 & 0.520 \\
\hline
\end{tabular}

${ }^{1}$ Averages with different letters on the same column differ statistically by Tukey test at $5 \%$ probability.
To evaluate the animal growth, it is important to know the variations occurring with the measures of weight gain, however, knowing only the daily WG rate is not sufficient. Although the Ross strain has higher WG than the other strains, the Hubbard strain showed a smaller reduction after reaching its maximum, reaching smaller variations between males and females of this strain, resulting in more uniform mixed batches.

The Ross strain achieved the best results in performance parameters and males were the most profitable. The broiler chicken strains have different yields of carcass and cuts. Cobb and Ross strains have higher breast yield, while the strains Hubbard and French have higher yields of drumstick and thigh. Females have higher viscera yield in relation to males.

\section{REFERENCES}

Api I, Takahashi SE, Mendes AS, Refati R, Rostelatto R. Efeito da sexagem e linhagens sobre o desempenho e rendimento de carcaça de frangos de corte. Ciência Animal Brasileira 2017;18(1):1-10.

Cheema MA, Qureshi MA, Havenstein GB. A comparison of the immune response of a 2001 commercial broiler with a 1957 randombred broiler strain when fed representative 1957 and 2001 broiler diets. Poultry Science 2003;82(1):1519-1529.

Da Costa MJ, Zaragoza-Santacruz S, Frost TJ, Halley J. Straight-run vs sex separate rearing for 2 broiler genetic lines Part 1: Live production parameters, carcass yield, and feeding behavior. Poultry Science 2017;96(1):2641-2661

Dalólio FS, Moreira J, Vaz DP, Albino LFT, Nunes RV, Pinto GVD. Digestible lysine for broilers from different commercial strains in the final phase. Acta Scientiarum. Animal Sciences 2016;38(1):411-416. 
Danisman R, Gous RM. Effect of dietary protein on the allometric relationships between some carcass portions and body protein in three broiler strains. South African Journal of Animal Science 2011;41(1):194-208.

Emmans GC. A method to predict food intake of domestic animals from birth to maturity as a function of time. Journal of Theoretical Biology 1997;186:189-199.

Faridi A, Sakomura NK, Golian A, Marcato SM. Predicting body and carcass characteristics of 2 broiler chicken strains using support vector regression and neural network models. Poultry Science 2012;91:32863294.

Fernandes JIM, Bortoluzzi C, Triques GE, Garcez Neto AF, Peiter DC. Effect of strain, sex and age on carcass parameters of broilers. Acta Scientiarum. Animal Sciences 2013;35(1):99-105.

Garcia Neto M, Campos EJ. Suscetibilidade de linhagens de frangos de corte à síndrome ascítica. Pesquisa Agropecuária Brasileira 2004;39(1):803808.

Gompertz, B. On the nature of the function expressive of the law of human mortality, and on a new mode of determining the value of life contingencies. Philosophical Transactions of the Royal Society of London 1825;115:513-583.

Gous RM. Modeling as a research tool in poultry science. Poultry Science 2014;93:1-7.

Havenstein GB, Ferket P, Quresh MA. Carcass composition and yield of 1991 vs 1957 broilers when fed "typical" 1957 and 1991 broiler diets. Poultry Science 1994a;73(1):1795-1804.

Havenstein GB, Ferket P, Scheideler SE, Larson BT. Growth, livability, and feed conversion of 1957 vs 1991 broilers when fed "typical" 1957 and 1991 broiler diets. Poultry Science 1994b;73(1):1785-1794.

Kessler AM , Snizek PN , Brugalli I. Manipulação da quantidade de gordura na carcaça de frangos. Anais da Conferência Apinco de Ciência e Tecnologia Avícolas; 2000; Campinas, São Paulo. Brasil. Campinas: FACTA; 2000. p.107-133.
Lopez KP, Schilling MW, Corzo A. Broiler genetic strain and sex effects on meat characteristics. Poultry Science, 2011;90:1105-1111.

Marcato SM, Sakomura NK, Fernandes JBK, Siqueira JC, Dourado LRB, Freitas ER. Crescimento e deposição de nutrientes nos órgãos de frangos de corte de duas linhagens comerciais. Revista Brasileira de Zootecnia 2010;39(1):1082-1091.

Nangsuay A, Meijerhof R, Van Den Anker I, Heetkamp MJW; Kemp B, Van Den Brande H. Development and nutrient metabolism of embryos from two modern broiler strains. Poultry Science 2015;94(1):2546-2554.

Peak SD, Walsh TJ; Benton CE, Brake J. Effects of two planes of nutrition on performance and uniformity of four strains of broiler chicks. The Journal of Applied Poultry Research 2000;9(2):185-194.

Rostagno HS, Albino LFT, Donzele JL, Gomes PC, Oliveira RF, Lopes DC. Tabelas brasileiras para aves e suínos: composição de alimentos e exigências nutricionais. $3^{\mathrm{a}}$ ed. Viçosa: UFV/DZO; 2011. 252 p.

Sakomura NK, Gous RM, Marcato SM, Fernandes JBK. A description of the growth of the major body components of 2 broiler chicken strains. Poultry Science 2011;90(1):2888-2896

Sakomura NK, Silva EP, Dorigam JCP, Gous RM, St Pierre N. Modeling amino acid requirements of poultry. Journal Applied Poultry Research 2015:267-282.

SAS - Statistical Analysis System. SAS user's guide. Cary: SAS Institute; 2002. $1686 p$

Stringhini JH Laboissiere M, Muramatsu K, Leandro NSML, Café MB. Avaliação do desempenho e rendimento de carcaça de quatro linhagens de frangos de corte criadas em Goiás. Revista Brasileira de Zootecnia 2003;32(1):183-190.

Vieira SL, Olmos AR, Berros J, Freitas DM, Coneglian JBL, Peña JEM. Respostas de frangos de corte fêmeas de duas linhagens a dietas com diferentes perfis protéicos ideais. Ciência Rural 2007;37(1):1753-1759.

Zuidhof MJ, Scheider BL, Carney VL, Korver DR, Robinson FE. Growth, efficiency, and yield of commercial broilers from 1957, 1978, and 2005. Poultry Science 2014;93(1):2970-2982. 
